\title{
Antydemoniczny charakter sakramentu pokuty i pojednania
}

Soteriologiczny charakter wszystkich sakramentów wypływa z Misterium Paschalnego Chrystusa, dokonanego w Duchu Świętym z woli Boga Ojca. Wszystkie one bowiem, każdy na swój sposób, są kontynuacją wyzwalającej działalności Boga, który przenosi człowieka z ciemności grzechu i władztwa Szatana do „swego przedziwnego światła” (1 P 2, 9). Grzech jako więzy łączące ludzi z domeną „władcy tego świata” (J 12, 31) nie ma racji bytu w przestrzeni sakramentalnego dialogu odpowiednio usposobionego człowieka z Chrystusem Zbawcą. Jest to szczególnie widoczne w sakramentach udzielanych „na odpuszczenie grzechów”, a mianowicie w chrzcie świętym, Ofierze Eucharystycznej oraz w sakramencie pokuty i pojednania. Jako takie posiadają wymiar jednoznacznie i fundamentalnie antydemoniczny, ponieważ zrywają powiązania z największym nieprzyjacielem człowieka, chcącym wciągnąć go w swój bunt przeciw Bogu i doprowadzić go do wiecznej rozpaczy. Poza tym pozwalają nawiązać utraconą przez grzech więź z Bogiem i z drugim człowiekiem, co jest totalnym przeciwieństwem dążeń „tego, który dzieli”.

Jak już wspomniano w poprzednich artykułach ${ }^{2}$, zwycięstwo nad grzechem, Szatanem i śmiercią, dzięki Chrystusowemu dziełu zbawienia, dokonuje się

\footnotetext{
Jan Paweł II, List apostolski Mulieris dignitatem [dalej: MD], nr 9, w: Jan Paweł II, Dzieła zebrane, t. 3, Kraków 2007, przyp. 29.

2 Por. M. Ficoń, Antydemoniczny charakter sakramentu chrztu świętego i sakramentu bierzmowania, „Analecta Cracoviensia” 48 (2016), s. 25-40; M. Ficoń, Antydemoniczny charakter sakramentu Eucharystii, „Analecta Cracoviensia” 49 (2017), s. 7-28.
} 
w chrzcie, przyjmowanym „na odpuszczenie grzechów” oraz w Eucharystii, podczas której uobecnia się męka Chrystusa, a Kościół ofiaruje Bogu za zbawienie świata Ciało za nas wydane i Krew za nas wylaną „na odpuszczenie grzechów”. Przebaczenie i odpuszczenie ludzkich grzechów dokonuje się wewnątrz Ofiary Eucharystycznej. W niej obecny jest Chrystus, który zostaje złożony na ołtarzu jako „Ofiara naszego pojednania” (III Modlitwa eucharystyczna), aby przez Ducha Świętego „zjednoczyć nas wszystkich” (II Modlitwa eucharystyczna $)^{3}$. Najświętsza Ofiara jako uobecnienie tajemnicy paschalnej Chrystusa jest „szczytem i źródłem wszelkiego jednania”, dlatego z niej wypływa skuteczność sakramentu pokuty i pojednania ${ }^{4}$.

Widać zatem ścisły związek między tymi dwoma sakramentami. Z jednej strony pełne uczestnictwo w Eucharystii, która jest skuteczna wobec grzechów i ma nad nimi moc, wymaga nieustannego nawracania się i osobistej odpowiedzi na wezwanie: „W imię Chrystusa prosimy: pojednajcie się z Bogiem” (2 Kor 5, 20), najpełniej realizujące się na drodze pokuty przez sakrament pojednania. Warunkiem odpuszczenia grzechów w Eucharystii jest bowiem godne zbliżenie się do niej ${ }^{5}$. Z drugiej strony, owa miłość Eucharystii i wymóg trwania w łasce Bożej, by móc godnie do niej przystąpić, prowadzi do coraz głębszego docenienia sakramentu pokuty i pojednania ${ }^{6}$. Zerwanie z grzechem, $\mathrm{z}$ okazją do zła, odrzucenie pokus, naprawienie zgorszeń czy postanowienie poprawy jest bowiem ofiarą, którą mamy złożyć na ołtarzu podczas sprawowania Eucharystii. Ta metanoia, całkowita przemiana, wyrzeczenie się Szatana, spraw jego i grzechu, wiara w Jezusa Chrystusa i życie na Jego kształt przy prowadzeniu Jego Ducha sprawia dopiero, że uczestnictwo w Eucharystii przynosi zamierzony owoc. Racją bytu sakramentu pokuty jest zatem podtrzymywanie nieustannego dziękczynienia i to, aby „Eucharystia sprawowała się najpełniej”7. Więź między Eucharystią a sakramentem pojednania przypomina również o grzechu i jego wymiarze społecznym, bowiem nie jest on nigdy rzeczywistością wyłącznie indywidualną, ale zawsze stanowi ranę zadaną wspólnocie Kościoła, w którą jesteśmy włączeni przez chrzest. Rezultatem drogi

3 Obrzędy pokuty dostosowane do zwyczajów diecezji polskich, red. Komisja ds. Kultu Bożego, Katowice 1981, Wprowadzenie teologiczno-pastoralne 2.

4 Por. A. Skowronek, S. Czerwik, M. Czajkowski, Sakrament pokuty, Katowice 198o, s. 183.

5 Zob. Jan Paweł II, Encyklika Ecclesia de Eucharistia [dalej: EE], Warszawa 2007, nr 34; por. W. Świerzawski, Sakramenty święte. Sakrament pokuty i pojednania, Wrocław 1984, s. 20.

6 Zob. Benedykt xvi, Adhortacja apostolska Sacramentum Caritatis [dalej: sc], Kraków 2007, nr 20; Ee 36; Katechizm Kościoła Katolickiego, Poznań 1994, nr 1385.

7 W. Świerzawski, Sakramenty święte. Sakrament pokuty i pojednania, dz. cyt., s. 192; por. s. 36. 
nawrócenia jest również przywrócenie pełnej komunii eklezjalnej wyrażającej się w ponownym przystąpieniu do stołu eucharystycznego ${ }^{8}$. Sakrament pokuty i pojednania pełni zatem bardzo ważną rolę w dziele pojednania, które przywróciło więzi zerwane przez grzech. W celu należytego zrozumienia jego istoty oraz fundamentalnej roli w dziele „zniszczenia dzieł diabła” (1 J 3, 8), trzeba najpierw pochylić się nad naturą i konsekwencjami rzeczywistości grzechu.

\section{Teologia grzechu i jego diaboliczne konotacje}

Najprostszą, najbardziej znaną i najtrafniejszą definicją grzechu jest określenie go jako „odwrócenie się od ostatecznego celu, którym jest Bóg”, i skierowanie ku komuś lub czemuś, co Bogiem nie jest ${ }^{9}$. Grzech stwarza w człowieku rzeczywistość bardziej poddaną jego własnym ludzkim słabościom i bardziej otwartą na sugestie Szatana. Nie zostawia ona wolnej przestrzeni dla panowania Boga, będącego Źródłem życia i radości. Dlatego, zamiast w oczekiwanej wolności i świetle, grzesznik pogrąża się w mrocznej niewoli:

Winy wasze wykopały przepaść między wami a waszym Bogiem; wasze grzechy zasłoniły Mu oblicze przed wami [...]. Oczekiwaliśmy światła, a oto ciemność, jasnych promieni, a kroczymy w mrokach (Iz 59, 2. 9).

Dzieje się tak, ponieważ stworzony na obraz i podobieństwo Boże człowiek (por. $\mathrm{Rdz} 1,26-27$ ) staje się $\mathrm{w}$ pełni samym sobą dopiero w zjednoczeniu z Bogiem - swym Stwórcą, który zna każdego lepiej niż on sam. Oderwany od tej jedności człowiek nie potrafi dojść do ładu z samym sobą i miota się między innymi celami, z których nigdy żaden nie będzie ostateczny i nie będzie w stanie zaspokoić pragnień jego serca ${ }^{10}$. Ta stopniowa degradacja ma go doprowadzić do rozpaczy, a w ostateczności do samopotępienia. Zły duch sprzeciwia się Bogu, a nie mogąc uderzyć bezpośrednio w Niego, bazuje na prawdzie, że największą obrazą Boga jest wyrządzenie przez człowieka

${ }^{8}$ Zob. sc 20; Sobór Watykański II, Konstytucja dogmatyczna o Kościele Lumen gentium, nr 1, w: Sobór Watykański II, Konstytucje, dekrety, deklaracje, red. M. Przybył, Poznań 2002.

9 Por. Tomasz Akwinu, Suma teologiczna, t. 12: O wadach i grzechach (1-2, q. 71-89), przetłumaczył i objaśnieniami zaopatrzył o. F. W. Bednarski op, London 1965, zag. 77, art. 8, Odpowiedź.

${ }^{10}$ Zob. Sobór Watykański II, Konstytucja duszpasterska o Kościele w świecie współczesnym Gaudium et spes [dalej: Gs], nr 21, 37, w: Sobór Watykański II, Konstytucje, dekrety, deklaracje, dz. cyt. 
krzywdy samemu sobie i innym przez grzech. Jego destrukcyjne zamysły względem ludzkości potwierdzają wszystkie dane Objawienia, w których Zły się pojawia. Każdy grzech bowiem, i ten pierwszy, i każdy kolejny, posiada wymiar ludzki i rys diaboliczny ${ }^{11}$, to znaczy tworzący podziały oraz odrywający od życia, szczęścia i pokoju. Bardzo obrazowo przedstawił tę prawdę Tertulian, twierdząc, że człowiek, który popełnia grzech, stawia na pierwszym miejscu diabła - nieprzyjaciela Boga i „sobą samym sprawia mu radość tak wielką,

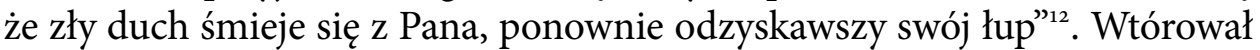
mu Orygenes, pisząc, że grzech to wyparcie się Boga i powrót do Szatana, którego na chrzcie świętym się wyrzekło ${ }^{13}$.

Opierali się oni niewątpliwie na danych biblijnych, które przedstawiają prawdę o tym, że człowiek miał możliwość życia w prawdzie i miłości, które mógł jedynie odnaleźć, żyjąc w przyjaźni ze Stwórcą, jednakże oderwał się od Niego pod wpływem „ojca kłamstwa” (J 8, 44), który „trwa w grzechu od początku” (1 J 3,8) i już „został osądzony” (J 16, 11). Jego grzech jako czystego ducha zaistniał w świecie stworzonym, zanim pojawił się człowiek, i jest niepomiernie cięższy od ludzkiego grzechu, dlatego „tchnienia zła” ze strony diabła nie można porównywać ze złem nieposłuszeństwa ze strony człowieka, jednakże:

to nieposłuszeństwo oznacza odwrócenie się od Boga, oznacza poniekąd zamknięcie się ludzkiej wolności względem Niego. Oznacza również pewne otwarcie się tejże wolności - ludzkiego poznania i woli - wobec tego, który jest „ojcem kłamstwa”. Akt świadomego wyboru nie tylko jest „nieposłuszeństwem”, ale niesie z sobą również pewną podatność w stosunku do tej motywacji, jaka zawiera się $\mathrm{w}$ pierwszej namowie do grzechu i motywacji nieustannie ponawianej w ciągu całych dziejów człowieka na ziemi: „[...] wie Bóg, że gdy spożyjecie owoc z tego drzewa, otworzą się wam oczy i tak jak Bóg będziecie znali dobro i zło"14.

${ }^{11}$ Zob. MD 9.

${ }^{12}$ Cyt. za: Chrzest i pokuta w Kościele starożytnym, oprac. J. Słomka, Kraków 2004, s. 176.

13 Por. Chrzest i pokuta $w$ Kościele starożytnym, dz. cyt., s. 95.

${ }^{14}$ Jan Paweł II, Encyklika Dominum et Vivificantem [dalej: Dv], nr 37, Warszawa 2007. Podobnie pisze Jan Paweł II w encyklice Veritatis splendor (Warszawa 2007), nr 1: „W następstwie tajemniczego grzechu pierworodnego, popełnionego za poduszczeniem Szatana, który jest «kłamcą i ojcem kłamstwa» $(J$ 8, 44), człowiek ustawicznie doznaje pokusy, by odwrócić wzrok od Boga żywego i prawdziwego i skierować go ku bożkom (por. 1 Tes 1, 9), przemieniając «prawdę Bożą w kłamstwo» (por. Rz 1, 25); przytępia to również jego zdolność poznawania prawdy i osłabia wolę poddania się jej. W konsekwencji człowiek, ulegając relatywizmowi i sceptycyzmowi (por. J 18, 38), zaczyna szukać złudnej wolności poza samą prawdą". 
To zamknięcie na Boga i otwarcie się na działanie i sugestie ducha zła to pierwszy, ale nie jedyny skutek grzechu, co zostanie poddane szerszej analizie w dalszej części artykułu. Ważnym momentem jest przede wszystkim niedopuszczenie do uległości pokusie diabła, który próbuje swym „,anty-Słowem”, czyli „przeciw-Prawdą” zakłamać to, kim jest człowiek oraz jakie są nieprzekraczalne granice jego bytu i wolności. Przewrotny „geniusz podejrzeń” stara się zafałszować równocześnie prawdę o tym, kim jest Bóg, stawiając Go w stan podejrzenia i oskarżenia w świadomości Jego własnych stworzeń, próbując „Zakłamać” absolutne Dobro i stwórczą Miłośćc ${ }^{15}$.

Scena pierwszego grzechu człowieka przypomina perwersję, butę i bezczelność Szatana, który wiele wieków później stara się kłamstwem przywieść do grzechu samego Boga-Człowieka (por. Mt 4, 1-11; Łk 4, 1-13; Mk 1, 12). Szatan próbował wtedy zmusić Chrystusa do zaprzeczenia samemu sobie, uderzając w Jego najsłabszy punkt - ludzką naturę. Ludzka wola Jezusa zawsze była jednak zjednoczona z Jego wolą Boską, która natychmiast odrzuciła przewrotne sugestie kusiciela. Właśnie pokusa jest najczęściej wykorzystywaną do ataku szatańską bronią. Warto zastanowić się nad tym, jak duży wkład w ludzki grzech ma zły duch i co dzięki niemu chce uzyskać.

\subsection{Szatańska pokusa $i$ jej udział w ludzkim grzechu}

Na pytanie o to, w jakim stopniu popełnienie grzechu jest sprawą człowieka, a w jakim stopniu działaniem diabelskim, odpowiada wielu znamienitych teologów i wszyscy zgadzają się co do tego, że grzech jest niewątpliwie aktem ludzkiej woli, a człowiek mógłby zgrzeszyć również bez udziału diabła, chociaż Biblia ukazuje bezsprzeczny związek między nim a grzechem. Właściwa i dostateczna przyczyna grzechu nie leży poza człowiekiem, ale znajduje się w nim samym - to jego wolność, osobiste decyzje i czyny. Poza tym, oprócz fomes peccati, są jeszcze różne słabości natury, wynikające $z$ uwarunkowań biologicznych, społecznych i kulturowych, zranienia w sferze duchowej i psychicznej. Jednakże, pod ludzką warstwą grzechu działają czynniki, które stawiają go na pograniczu, tam, gdzie wola, świadomość i wrażliwość człowieka spotyka się $\mathrm{z}$ siłami ciemności ${ }^{16}$.

${ }_{15}$ Zob. DV 37.

${ }_{16}$ Zob. Jan Paweł II, Adhortacja apostolska Reconciliatio et poenitentia [dalej: RP], Libreria Editrice Vaticana 1984, nr 14; Tomasz z Akwinu, Suma teologiczna, t. 12, dz. cyt., zag. 75, art. 3, Odpowiedź; M. Jagodziński, „Zwyczajne” działanie Boga w sakramentach w kontekście kontrowersyjnych koncepcji teologiczno-pastoralnych, „Studia Teologii Dogmatycznej” 3 (2017), s. 58. 
Na podstawie danych Objawienia i doświadczenia codziennego życia można powiedzieć, że Szatan z pewnością pełni niemałą rolę w kuszeniu do grzechu i doprowadzeniu do większego otwarcia na swoje zgubne podszepty, jest inicjatorem i podżegaczem do zła, ale nie jest jego bezpośrednim sprawcą. Niebezpieczne byłoby nazywanie grzechu bramą, przez którą zły duch wkrada się niepostrzeżenie w życie człowieka i staje się jego ukrytym reżyserem. Nie powinno się w ten sposób demonizować rzeczywistości, ponieważ może to prowadzić do spychania odpowiedzialności za zło, u którego podstaw zawsze stoją osobiste ludzkie wybory i działania ${ }^{17}$.

Mechanizmy rządzące uwikłaniem się człowieka w grzech oraz rolę złego ducha w tym akcie wyjaśniał Tomasz z Akwinu w Sumie teologicznej. Stwierdził w niej, że tylko wola człowieka może być bezpośrednią przyczyną jego grzechu i nie można powiedzieć, iż jest nią diabeł, pomimo tego, że nakłania do grzechu, ponieważ tylko Bóg jest w stanie poruszyć ludzką wolę, do czego zły duch nie jest zdolny. Tomasz nie wykluczył jednak nigdzie jego udziału w zachęcaniu człowieka do zła. Kusiciel może to czynić, namawiając go do grzechu lub podsuwając jakiś atrakcyjny przedmiot. W ten sposób pragnie choć pośrednio wpłynąć na rozum i wolę, przyćmić ich światło, oddziałując na wyobraźnię i pożądanie zmysłowe. Pobudza ludzką fantazję, by wywołać zamierzone przez siebie obrazy oraz działa na popędy zmysłowe, by wzbudzić odpowiednie uczucia. Wskutek podniecenia uczuciowego człowiek postanawia uczynić to, co zostało podsunięte wyobraźni i uznaje za dobro to, do czego skłania go uczucie. Ciągle jednak grzech zależy od jego woli, a diabeł nie może go zmusić do popełnienia zła, ponieważ nie może sprawić, aby rozum nie opierał się pożądaniu ${ }^{18}$.

Według Doktora Anielskiego diabeł jest przyczyną wszystkich ludzkich grzechów niebezpośrednio i przygodnie w tym znaczeniu, że skusił do grzechu pierwszego człowieka, czego konsekwencją było skażenie ludzkiej natury tak, że wszyscy ludzie skłonni są do grzechu, podobnie jak przyczyną spalenia drzew było ich wysuszenie, wskutek czego stały się łatwopalne. Dlatego ludzie zgrzeszyliby nawet bez demona, gdyby do ich pożądań wkradł się bezrozumny nieład zależny od wolnej woli. $\mathrm{Z}$ tego powodu niewolnikiem diabła staje się tylko ten człowiek, który mu się poddał dobrowolnie, a więc zgrzeszył samorzutnie. Ludzie ciągle są namawiani do zła przez złego ducha, nieustannie

${ }_{17}$ Zob. Opinia teologiczna Komisji Nauki Wiary KEP w sprawie tzw. spowiedzi furtkowej, nr 10; http://episkopat.pl/decyzja-kep-w-sprawie-tzw-spowiedzi-furtkowej (13.06.2018).

${ }_{18}$ Por. Tomasz z Akwinu, Suma teologiczna, t. 12, dz. cyt., zag. 8o, art. 1-3. 
doznają skłonności do grzechu wskutek jego sugestii, więc ich grzechy nie są tej samej miary co grzech diabła. On zgrzeszył bez żadnych pokus z niczyjej strony, dlatego jego przestępstwo jest nieodwracalne i nie da się go naprawić ${ }^{19}$. Zatem „szatańskie oszustwo", jak Andrzej z Krety nazwał pokusę ${ }^{20}$, jest najprostszą drogą do popełnienia grzechu przez ludzką wolę. Tomasz dodał, że zwykle demony nie działają ostentacyjnie, ale namawiają do grzesznych drobiazgów, powszednich czynności, by człowieka pociągnąć do pewnej zażyłości z sobą i w ten sposób doprowadzić go do grzechu śmiertelnego ${ }^{21}$.

W rozważaniach nad zagadnieniem przyczyny grzechu najlepszym rozwiązaniem będzie więc znaleźć złoty środek pomiędzy dwoma skrajnościami: przypisywaniem Szatanowi całkowitej odpowiedzialności za każdy ludzki grzech oraz totalnym bagatelizowaniem jego wpływu na ludzkie decyzje. Głęboką intuicję i prawdę o tym, że nie można lekceważyć złego ducha, przekazywał Jan Paweł II, który wielokrotnie ostrzegał przed działaniem Złego. W liście do młodych całego świata zachęcał, by nazywać po imieniu pierwszego sprawcę zła i ujawnił jego taktykę ukrytego zaszczepiania zła, by rosło z samego człowieka, z samych ustrojów i układów, by stawało się coraz bardziej grzechem „strukturalnym”, a coraz mniej „personalnym” i aby człowiek, myśląc, że jest coraz bardziej „wyzwolony” od grzechu, był coraz bardziej w nim pogrążony ${ }^{22}$.

W podobnym tonie pisze papież Franciszek w adhortacji Gaudete et exsultate, skupiając się na przestrodze, by nie bagatelizować wpływu kusiciela:

Nie myślmy więc, jakoby był to jakiś mit, wyobrażenie, symbol, postać czy pojęcie. To oszustwo, które prowadzi nas do osłabienia czujności, do braku troski o siebie i do bycia bardziej narażonymi. On nie musi nas opętać. Zatruwa nas nienawiścią, smutkiem, zazdrością, wadami. I tak, gdy ograniczamy obronę, on to wykorzystuje, aby zniszczyć nasze życie, rodziny i wspólnoty, bo „jak lew ryczący krąży szukając kogo pożreć” $\left(1 \mathrm{P}_{5}, 8\right)^{23}$.

19 Por. Tomasz z Akwinu, Suma teologiczna, t. 12, dz. cyt., zag. 8o, art. 4.

${ }^{20}$ Zob. Andrzej z Krety, Wielki Kanon Pokutny, Hajnówka 2004, s. 65. Zdając sobie również sprawę z ludzkiej słabości, nazywa grzech „sprzedaniem samego siebie swoim wadom” (Wielki Kanon Pokutny, dz. cyt., s. 19).

${ }^{21}$ Por. Tomasz z Akwinu, Suma teologiczna, t. 12, dz. cyt., zag. 89, art. 4, ad. 3.

${ }_{22}$ Zob. Jan Paweł II, List apostolski Parati semper do młodych całego świata z okazji Międzynarodowego Roku Młodzieży, nr 15, w: Jan Paweł II, Dzieła zebrane, t. 3, Kraków 2007.

${ }^{23}$ Franciszek, Adhortacja apostolska Gaudete et exsultate [dalej: GE], $\mathrm{nr}$ 161, http://w2.vatican. $\mathrm{va} /$ content/francesco/pl/apost_exhortations/documents/papa-francesco_esortazione-ap_20180319_ gaudete-et-exsultate.html (6.06.2018). 
Jan Paweł in zlecił nawet pasterzom Kościoła katechezę na temat kuszenia i pokus, aby wierni brali przykład z Chrystusa i wiedzieli, jak się mają zachować w momencie pokusy oraz żeby mogli postrzegać ją jako okazję do wzrostu w wierności i zgodności życia z wiarą ${ }^{24}$.

Grzechy nie są zatem wynikiem tylko ludzkiej słabości. Przyczynia się do nich także zły duch, dlatego Chrystus pochylał się nad grzesznikiem i przebaczał, a występował przeciwko „ojcu kłamstwa” (J 8, 44). Grzesznik musi mieć zatem świadomość, że walcząc z grzechem w sobie, walczy także z Szatanem (por. Ef 6, 10-12).

\subsection{Konsekwencje grzechu jako skutek relacji z Szatanem}

Związki grzechu człowieka $\mathrm{z}$ diabłem ukazane są zaraz na początku Pisma Świętego, gdzie zło i śmierć wchodzi do świata ludzi za przyczyną Złego (por. Mdr 2, 24). Pomimo tego, że ludzki grzech został popełniony z wolnej woli, obecność ducha kłamstwa przy pierwszym nieposłuszeństwie i każdym następnym jest bardzo znacząca, dlatego nie powinno się wyłączać go całkowicie z tego procesu w imię „odmitologizowania” rzeczywistości czy skupionej na psychologii antropocentrycznej wizji grzechu. Człowiek, namówiony przez niego i pociągnięty własną pychą, odmówił posłuszeństwa Stwórcy, nie uwierzył Jego słowom, odrzucił Jego autorytet i prawo moralne, które Bóg wpisał w ludzkie serce (por. Rdz 3, 1-14). Odrzucenie swego Pana jako tego, który stwarza życie i podtrzymuje je w istnieniu, było aktem samobójczym, ponieważ w człowieku zaburzeniu uległa wewnętrzna równowaga, zaczęły wybuchać w nim sprzeczności i konflikty, a wtedy nieuchronnie obrócił się przeciwko innym ludziom i światu stworzonemu. Każdy grzech jest bowiem zarazem indywidualny i społeczny, ponieważ odrzucenie ojcowskiej miłości Boga zawsze skutkuje podziałami w łonie ludzkości ${ }^{25}$, a na tym zależy najbardziej „temu, który rozdziela”.

Człowiek ma tendencje do wybielania swoich czynów, zrzucania odpowiedzialności za zło na innych i do stopniowego stępiania wrażliwości swego sumienia, co w końcu prowadzi do przytłumienia poczucia obecności Boga, a w konsekwencji do utraty poczucia grzechu ${ }^{26}$. Osłabiona wola i zaciemniony rozum stają się bardziej podatne na sugestie kusiciela, który później nie musi wkładać w zwodzenie człowieka większego wysiłku, ponieważ grzesznik nie potrafi dostrzec, że czyni coś złego. Już Cezary z Arles ostrzegał:

\footnotetext{
${ }^{24}$ Zob. RP 26.

${ }^{25}$ Por. RP 10.14-15.

${ }^{26}$ Por. RP 18.
} 
Niech was nikt nie zwodzi! Najgorszym rodzajem grzechu jest niezrozumienie jego istoty. [...] Żaden z grzeszników nie jest bardziej godny pożałowania, niż ten, który uważa, że nie ma czego opłakiwać. Wiele występków, i to tych bardziej niebezpiecznych, uważa się za lekkie. Jeszcze bardziej szkodzą te, które przez niektórych nie są uznawane za grzechy. Żadne zło nie uwodzi łatwiej niż to, które nie jest uważane za takie ${ }^{27}$.

Istnieje zatem pilna potrzeba uświadomienia sobie grzechu i jego czterech podstawowych wymiarów, by zobaczyć, w jakim stopniu zostajemy wciągnięci $\mathrm{w}$ intrygi Złego oraz jakie to ma destrukcyjne konsekwencje. To pierwszy krok do odcięcia się od dotychczasowego, podporządkowanego diabłu życia i wyrwania korzeni tkwiącego w nas zła.

Pierwszą konsekwencją grzechu jest zerwanie więzi z Trójjedynym Bogiem. Przykład pierwszych ludzi ilustruje istotę tego osobowo-egzystencjalnego aktu. Stwórca obdarzył ludzi istnieniem, miłością i godnością bycia Jego obrazem; wezwał ich przez to do pełniejszego udziału w swym życiu, będącym żywą wspólnotą miłości, i do bycia godnymi tego uczestnictwa. Jednakże człowiek za podszeptem węża zdradził dar Bożej miłości (por. Oz 6, 6), odrzucił wzniosłe powołanie, które wyznaczył mu Stwórca, Jego prawo i Jego samego, idąc za porządkiem ustanowionym przez siebie. Pycha doprowadziła go do tego, że odrzucił Boski autorytet, zwątpił w absolutność słowa Bożego. Zamiast odwzajemnić przyjaźn i miłość Stwórcy, człowiek zbuntował się przeciw Niemu, zerwał z Nim relację i nie pozwolił Mu się obdarować, widząc w Nim tyrana (por. $\operatorname{Rdz} 3,5-7$ ). Ludzki grzech bezpośrednio Boga nie dotyka (por. Jr 7, 18; Hi 35, 6), natomiast człowieka niszczy od środka. Człowiek, ontycznie zależny od Boga, zrywając związek z kochającym go Stwórcą i opierając się działaniu łaski, wyrządza bowiem krzywdę samemu sobie - zostaje wydany na pastwę ciemności i jej sług (por. Jr 2, 19; J 3, 19; 9, 41) ${ }^{28}$.

Współczesny grzesznik, w przeciwieństwie do prarodziców, nie ma wrażenia, że kieruje swe czyny przeciw Bogu, ponieważ traktuje Go obojętnie i lekceważy. Zwykle dąży do uzyskania jakiegoś, w jego mniemaniu, dobra, natomiast zło i jego powiązania w ogóle nie pojawiają się w jego świadomości. Najczęściej oddaje się egoistycznym zachciankom i nie opiera się naporowi zła ${ }^{29}$. Dlatego

${ }^{27}$ Cezary z Arles, Kazanie 144, 4; w: Cezary z Arles, oprac. A. Żurek, Kraków 2003, s. 284.

${ }_{28}$ Por. J. Orzeszyna, Społeczno-eklezjalny wymiar sakramentu pokuty, Kraków 1996, s. 64-69, 78; A. Skowronek, S. Czerwik, M. Czajkowski, Sakrament pokuty, dz. cyt., s. 71-72, 209-211.

${ }_{29}$ Por. A. Skowronek, S. Czerwik, M. Czajkowski, Sakrament pokuty, dz. cyt, s. 49. 
ważne jest położenie akcentu na antyteistyczny wymiar każdego grzechu, nawet gdyby nie jawił się on jako taki, ponieważ zaniedbanie podtrzymywania relacji z Bogiem, jest także zrobieniem kroku w tył na drodze do zbawienia. Na tym najbardziej zależy duchowi ciemności.

Autodestrukcja grzesznika stanowi zatem kolejny nieunikniony skutek grzechu. Wielu autorów, odwołując się do Objawienia zawartego w Piśmie Świętym, podkreślało, że grzech jako czyn osoby wywołuje najpierw skutki w samym grzeszniku, w jego relacjach z Bogiem i w jego duszy, osłabiając wolę i zaciemniając rozum, czyniąc go w ten sposób bardziej podatnym na podszepty złego ducha i bardziej nieczułym na zło grzechu ${ }^{30}$. Z tego powodu Tomasz z Akwinu uważał grzech za pewien rodzaj więzów, które najbardziej szkodzą grzesznikowi dlatego, że oddalają go od Boga ${ }^{31}$. Człowiek bowiem rozmija się z istotą własnej egzystencji, odrzuca życie ukierunkowane na Stwórcę, który ludzkiemu istnieniu nadaje pełny sens i uczy go kochać. Grzech stanowi zagrożenie dla ludzkiego zbawienia, ponieważ jest zaprzeczeniem i odmową miłości, nie tylko w sposób bezpośredni, lecz przede wszystkim w wyniku zaniedbania rozwoju nowych możliwości i braku otwarcia się na miłość coraz większą, której nieskończoność objawił czyn Chrystusa. Grzech hamuje w człowieku zryw do zamierzonego przez Boga ciągłego odkrywania i doświadczania Jego miłości ${ }^{32}$.

Taka sytuacja nie pozostaje bez konsekwencji dla grzesznika. Już Księga Rodzaju ukazuje destrukcyjne skutki, jakie niesie z sobą grzech. Nie należy ich jednak postrzegać jako kary Bożej. Bóg, dając człowiekowi wolność, pozwolił mu również doświadczyć konsekwencji swoich występków (por. Rdz 3, 7-13; Hi 8, 4; Prz 13, 6; Mdr 1, 12). Najpierw ludzie uciekają przed Bogiem (por. $\operatorname{Rdz} 3,8$ ), potem zamyka się przed nimi dostęp do drzewa życia (por. Rdz 3, 22-24), a zatem dotyka ich śmierć duchowa i wieczna, której znakiem jest śmierć fizyczna bez zmartwychwstania. Została ona wprowadzona na świat za pośrednictwem węża i jego pokusy, której człowiek uległ (por. Mdr 2, 24) ) $^{33}$. Teksty biblijne w wielu miejscach wskazują na wewnętrzne rozdarcie i nieporządek serca, jaki potem pojawia się w człowieku. Grzech alienuje go,

${ }^{30}$ Zob. RP 16; por. J. Orzeszyna, Społeczno-eklezjalny wymiar sakramentu pokuty, dz. cyt., s. 8 o.

${ }^{31}$ Por. Tomasz z Akwinu, Suma teologiczna, t. 29: Sakrament pokuty (3, qu. 84-9o), przełożył i w objaśnienia zaopatrzył R. Kostecki op, zag. 84, art. 3, wykład; Tomasz z Akwinu, Suma teologiczna, t. 30: Sakrament pokuty II (Suppl. 1-28), przełożył i w objaśniania zaopatrzył o. F. W. Bednarski op, zag. 3, art. 1, rozwiąz. 4.

${ }^{32}$ Por. A. Skowronek, S. Czerwik, M. Czajkowski, Sakrament pokuty, dz. cyt., s. 54.

33 Por. A. Skowronek, S. Czerwik, M. Czajkowski, Sakrament pokuty, dz. cyt., s. 209-210. 
ponieważ nadaje mu kierunek niezgodny z jego najgłębszymi aspiracjami i danym mu przez Boga powołaniem (por. Rz 7, 14-25). Skutkiem zerwania więzi z Bogiem jest przede wszystkim dezintegracja osobowości, ponieważ człowiek z natury ukierunkowany jest na Boga, w którym osiągnąć może szczęście, duchową pełnię oraz może być naprawdę sobą i realizować swoje człowieczeństwo. Grzech niszczy to podstawowe odniesienie, odcina od dopływu łaski, a człowiek bezskutecznie szuka swej autonomii, gubiąc się we własnej złudnej samowystarczalności. Zdradza samego siebie, bo sprzeniewierza się wewnętrznej godności płynącej z ładu ustanowionego przez Boga. Przez zranienie sumienia traci ośrodek duchowy i jedność osoby, która opierała się na działaniu zgodnym z jego osądem. Powstaje stan rozbicia, ponieważ grzesznik dostrzega rozbieżność między powinnością a zrealizowaną chęcią, przeżywa wewnętrzną dezaprobatę własnego czynu, czuje się przez niego pomniejszony ${ }^{34}$.

Kolejnym aspektem dzieła samozniszczenia w grzechu jest deprawacja własnej natury poprzez osłabienie woli w naturalnej dążności do dobra oraz zaciemnienie rozumu w zdolności do poznawania prawdy o Bogu i sobie samym. Człowiek, pogrążając się w ciemnościach zła, uniemożliwia samemu sobie poznanie prawdy (por. J 8, 43-47) i zamyka się na nią, dokonując przy tym przewrotnych ocen moralnych ( $2 \mathrm{P} 2,1-3)$. Władze wolitywno-poznawcze są bowiem ściśle związane ze sprawnością sumienia - jego prawdziwością, pewnością i wrażliwością. Dlatego aberracje woli i rozumu mogą doprowadzić nawet do znieczulenia na zło i braku niepokoju, pomimo popełnienia najgorszych zbrodni. Grzech powoduje również dezintegrację fizyczną i psychiczną człowieka, który mu się poddaje. Grzesznik ponosi bowiem konsekwencje swych złych czynów (por. $1 \mathrm{Krl} 8$, 32), doprowadzając do ruiny swe zdrowie

${ }^{34}$ Por. J. Orzeszyna, Społeczno-eklezjalny wymiar sakramentu pokuty, dz. cyt., s. 84-85. Obrazowo tę wewnętrzną dezintegrację ukazują ojcowie Kościoła. Cezary z Arles pisał: „Kto przez niedbalstwo pozwoliłby, aby w jego duszy przez długi czas przez złe czyny gromadziły się brudy i zaniedbałby codziennie oczyszczać ją dobrymi czynami, to nie tylko Bóg nie zechciałby go odwiedzić, ale nawet sam grzesznik nie mógłby ze sobą wytrzymać” (Kazanie 61, 1-3; w: Cezary $z$ Arles, dz. cyt., s. 178). Z kolei Andrzej z Krety oskarżał się z tego, że uległ „wrogowi oszustowi”: „Pogrzebałem obraz Twój i naruszyłem przykazania Twoje, całe piękno jest we mnie pomroczone i lampa zgasła od żądz” (Wielki Kanon Pokutny, dz. cyt., s. 121); „Skalałem szatę ciała mego, Zbawco, i zaciemniłem w sobie to, to zostało stworzone na Twój obraz i podobieństwo. Omroczyłem piękno duszy zadowalaniem pokus i cały rozum zupełnie uczyniłem prochem. Rozdarłem teraz pierwszą moją szatę, którą na początku utkał mi Stwórca i dlatego leżę nagi. Przyoblekłem się w podartą szatę, którą wąż utkał mi swą radą, przeto wstydzę się" (Wielki Kanon Pokutny, dz. cyt., s. 9). 
przez nadużycia moralne, bądź też doświadczając niepokoju duszy, ściśle związanego z niepokojem psychicznym i poczuciem winy, które może się skończyć frustracją, utratą szacunku do siebie, wewnętrzną dezaprobatą, poczuciem pustki, wyrzutami sumienia, a nawet nerwicą czy samoalienacją ${ }^{35}$. Można powiedzieć, że grzech depersonalizuje człowieka, czyniąc go ofiarą jego własnej pychy i pożądliwości. Do takiego właśnie „rozszczepienia” dąży diabeł, chcąc oderwać człowieka od Boga. Im więcej ulegnięcie jego namowom dokonuje spustoszeń w danym człowieku, tym większe ma on trudności w kontaktach z innymi ludźmi, we współżyciu społecznym, a zwłaszcza w relacjach rodzinnych. W ten sposób rozszerza się mysterium iniquitatis.

Zerwanie więzi z drugim człowiekiem to kolejny skutek ludzkiego grzechu, ponieważ tracąc fundament swego życia, jakim jest Bóg, człowiek traci jednocześnie podstawę dla właściwych postaw wobec bliźnich. W Biblii ukazuje tę prawdę scena $\mathrm{z}$ Księgi Rodzaju, w której kobieta i mężczyzna po grzechu wzajemnie się oskarżają (por. $\operatorname{Rdz} 3,12$ ), brat zabija brata (por. $\operatorname{Rdz} 4,2-16$ ), a rodzina ludzka zostaje rozbita (por. $\mathrm{Rdz} 11,4-9$ ). Co więcej, nierozerwalny związek między miłością Boga a miłością bliźniego potwierdza sam Jezus (por. Mt 22, 37-40). Wykroczenie przeciw miłości bliźniego jest zarazem grzechem wobec Boga (por. Mt 25, 45), a ten, kto nie kocha Boga, nie jest w stanie miłować bliźniego.

Z doświadczenia ogólnoludzkiego wiadomo, że człowiek realizuje prawdziwie siebie $w$ relacjach $z$ innymi ludźmi. Jednak kiedy traci łaskę i wewnętrzny pokój przez grzech, staje się coraz mniej zdolny do wykraczania poza siebie i nawiązywania autentycznych relacji z bliźnimi. Grzech niszczy najgłębszą

35 Por. J. Orzeszyna, Społeczno-eklezjalny wymiar sakramentu pokuty, dz. cyt., s. 87-93. Ojcowie porównują skutki ulegnięcia złu do chaosu, skażenia i rozszarpywania ciała przez dzikie zwierzęta: "Odzwierciedliłem w sobie nieporządek pokus, pożądaniem rozkoszy skaziłem piękno rozumu” (Andrzej z Krety, Wielki Kanon Pokutny, dz. cyt., s. 9); „Życie moje ciągle spędzałem w nocy, bowiem mrokiem i głęboką mgłą była dla mnie noc grzechu” (Andrzej z Krety, Wielki Kanon Pokutny, dz. cyt., s. 19); „ty duszo, zapaliłaś ogień Gehenny, w którym będziesz płonąć. Zraniony jestem i pełen strupów, oto strzały wroga przenikające duszę moją i ciało, oto rany, wrzody i strupy krzyczą od razów samowolnych mych żądz" (Andrzej z Krety, Wielki Kanon Pokutny, dz. cyt., s. 105). Według Cezarego z Arles ludzie zaniedbani moralnie mają w sobie jeden wielki chaos, grzechy rozrywają ich serca niczym dzikie zwierzęta i ranią je jak trujące ciernie. Ludzie zagłuszają je uciechami tego świata, a sumienia ich pełne fałszu i występku „nie mogą w ogóle zaznać spokoju, bo trawi ich wojna, jaką ze sobą toczą ich grzechy”. Porównuje grzechy do ukąszeń, szarpnięć, ognia pożerającego i kłów dzikich zwierząt oraz tarzania się w rozpuście i pijaństwie „niczym w kloakach najpaskudniejszych", które nie przyniosą im ani ukojenia, ani pokoju. Zob. Cezary z Arles, Kazanie 61, 3; w: Cezary z Arles, dz. cyt., s. 181-182. 
istotę człowieka, a co za tym idzie, jego zdolność kochania i czynienia innych szczęśliwymi. Dzieli ludzi, rozbija ich jedność i wzajemną miłość. Każdy grzech, nawet popełniony po kryjomu, zawsze niesie ze sobą skutki społeczne i wymierzony jest przeciw bliźnim. Niszczy nadprzyrodzone braterstwo ludzkości, której wspólnotę każdy jest zobowiązany budować, wzorując się na miłości trynitarnej. Grzesznik świadomie zrywający z Bogiem nie jest w stanie zobaczyć w drugim człowieku godności dziecka Bożego i stosuje wobec niego kryteria czysto naturalne, utylitarne i egoistyczne. Nie bierze pod uwagę zgubnych skutków grzechu, który skaża środowisko ludzkie przez zgorszenie i wytwarza atmosferę grzechu (por. Rdz 19, 4-5; 1 Mch 1, 11-15; 2 Mch 6, 3-7) ${ }^{36}$. Na mocy sprzężenia zwrotnego grzech może również „zaatakować” jednostkę od strony społeczeństwa, żyjącego niezgodnie z zasadami etycznymi i zdemoralizować ją tak, że zacznie przyjmować oceny i kryteria, jakimi kieruje się owo społeczeństwo ${ }^{37}$.

Grzech ochrzczonego wpływa również na kondycję Mistycznego Ciała Chrystusa (por. 1 Kor 12, 26). Jako taki stanowi zaporę na drodze do świętości dzieci Kościoła, ponieważ przez ich grzechy moc ciemności pogrąża w mroku jasny obraz Kościoła i utrudnia jego zbawczą misję (por. Rz 2, 24). Stanowi też odcięcie się od wspólnoty miłości z Duchem Jedności oraz wprowadzenie nieładu działania ludzkiego w świat rzeczy stworzonych jako tworzywa przyszłego królestwa ${ }^{38}$. Grzeszyć to znaczy pozbawiać Kościół rozwoju i mocy do budowania w świecie sprawiedliwości i pokoju.

Grzech człowieka odbija się również na jego relacji ze światem stworzonym. Nieposłuszeństwo i pycha człowieka przyniosła zgubne konsekwencje nie tylko dla jego życia, lecz także dla całej biosfery: pojawia się w niej śmierć, zniewolenie, bóle porodowe i bunt przeklętej ziemi, która zrodzi osty i ciernie (por. Rdz 3, 16-19; 4, 12). Stworzenie zostało poddane marności, panuje w nim stan bólu i udręki (por. Rz 8, 20-22), człowiek w pocie czoła musi zdobywać pożywienie i pokonywać opór materii. Odwrócenie się od Stwórcy zaowocowało postrzeganiem świata nie jako Bożego dzieła i daru, ale jako całkowicie $\mathrm{Mu}$ obcego i niebędącego miejscem realizacji Jego zamiarów. Dzieła Boże stworzone przez Niego jako dobre (por. $\mathrm{Rdz} 1,31$ ) są przez ludzi wykorzystywane w sposób niewłaściwy, niezgodny z rozumem i utylitarystyczny. Świat wskutek tego ulega stopniowej degradacji (por. Oz 4, 3), „odwzajemniając się”

\footnotetext{
${ }^{36}$ Por. J. Orzeszyna, Społeczno-eklezjalny wymiar sakramentu pokuty, dz. cyt., s. 96-97, 102.

37 Por. J. Orzeszyna, Społeczno-eklezjalny wymiar sakramentu pokuty, dz. cyt., s. 105.

${ }_{38}$ Por. GS 39.
} 
człowiekowi tym samym, poprzez katastrofy naturalne lub zafascynowanie go swymi zwodniczymi wartościami (por. $1 \mathrm{~J} \mathrm{2,} \mathrm{15-16)}$ ) $^{39}$.

Można zatem zauważyć, że każdy grzech ma dwie płaszczyzny teleologiczne - wertykalną, co znaczy, że wymierzony jest przeciw Bogu, i horyzontalną, bowiem skierowany jest przeciw samemu grzesznikowi, bliźniemu i światu stworzonemu. Te dwa wymiary wzajemnie się przenikają, co stanowi przeciwieństwo mądrości krzyża (por. 1 Kor 1, 17-24), który jednoczy ludzi z Bogiem i ludzi między sobą. Oczywiste jest zatem, że grzech to rzeczywistość ze wszech miar niszcząca, tak jak niszczące i destrukcyjne są zamiary „ojca kłamstwa” $(J$ 8, 44), by człowieka w tę rzeczywistość wciągnąć. Człowiek sam z siebie nie jest w stanie pokonać tych rozdarć, dlatego przyszedł Chrystus - po to, by „zniszczyć dzieła diabła” (1 J 3,8).

\section{Dzieło pojednania dokonane przez Chrystusa jako wydarzenie antydemoniczne}

Stwórca pozostaje wierny swemu odwiecznemu zamysłowi miłości nawet wtedy, gdy podpuszczony przed Złego i własną pychę człowiek nadużył wolności i odmówił Mu posłuszeństwa. Mimo tej przewrotności człowieka, „obficiej rozlała się łaska” (Rz 5, 20) i Bóg „bogaty w miłosierdzie” (Ef 2, 4) ulitował się nad nim (por. Mi 7, 19). Wyszedł do niego z inicjatywą pojednania, będącego czystym darem, dzięki dziełu Jezusa Chrystusa, który „nawiedził swój lud i wyzwolił go" (Łk 1, 68) jako Światłość przeciwstawiająca się ciemnościom grzechu (por. J 8, 12; 1, 4-9; 3, 19-21; 12, 46) i wyzwalająca $z$ jego niewoli (por. J 8, 34-36; Kol 1, 14). Dzięki śmierci na krzyżu i pełnemu miłości posłuszeństwu Chrystus przyniósł wszystkim zbawienie i stał się dla wszystkich „pojednaniem” i „pokojem” (por. Ef 2, 14-16). W Nim Bóg pojednał ze sobą świat, nie poczytując ludziom ich grzechów (por. $\mathrm{Rz}$ 5, 6-11; 2 Kor 5, 18-20).

Pojednanie jest koniecznością, ponieważ przez grzech nastąpił rozłam, z którego biorą początek wszystkie inne formy podziału w człowieku i wokół niego. Konieczne jest również uwolnienie od grzechu i całkowite jego wykorzenienie poprzez nawrócenie. Dlatego Chrystus przyszedł jako Pośrednik pojednania ludzi z Bogiem i między sobą, wzywał do pokuty i metanoi, przyjmował grzeszników, jednając ich z Ojcem (por. Łk 5, 20. 27-32; 7, 48), a szczytem posługi jednania była Jego Ofiara, ponieważ umarł za nasze grzechy i zmartwychwstał dla naszego usprawiedliwienia (por. $\mathrm{Rz} 4,25$ ). Do dziś modlimy

39 Por. J. Orzeszyna, Społeczno-eklezjalny wymiar sakramentu pokuty, dz. cyt., s. 119-121. 
się podczas III Modlitwy eucharystycznej: „Prosimy Cię, Boże, aby ta ofiara naszego pojednania $z$ Tobą sprowadziła na cały świat pokój i zbawienie"40.

Chrystus wylał również na ludzkość - „na odpuszczenie grzechów” - swego Ducha (por. J 20, 19-23), który świat przekonuje „o grzechu, o sprawiedliwości i o sądzie” (J 16, 8). Owo „przekonywanie” ma wymiar zbawczy dla człowieka i dla świata. „Sąd” bowiem odnosi się tylko do „władcy tego świata” (J 12, 31), czyli Szatana, wykorzystującego od początku dzieło stworzenia przeciw zbawieniu, przymierzu i zjednoczeniu człowieka z Bogiem. Duch Prawdy czyni to, aby kontynuować w świecie Chrystusowe dzieło zbawienia. Natomiast „przekonywanie” przez Niego o „sprawiedliwości”, czyli wypełnieniu zbawczej ekonomii, której ukrzyżowany i uwielbiony Chrystus jest centrum, służy odcięciu człowieka od „sądu”, czyli potępienia diabła - „rządcy świata tych ciemności” (Ef 6, 12). I tenże Duch, który „przenika głębokości Boga samego” (1 Kor 2, 10) i który jest Miłością Ojca i Syna, Darem i Źródłem wszelkiego obdarowania, przekonuje w pełni świat „o grzechu” i motywacji nieposłuszeństwa pierwszego człowieka ${ }^{41}$.

2.1. Odkupienie jako przywrócenie więzi zerwanych przez grzech za podszeptem Zlego

Duch Pojednania i Prawdy wyprowadza z „głębokości Bożych” odpowiedź na ludzki grzech. Przekonuje o nim, czyli wykazuje zło każdego grzechu oraz jego demoniczną otoczkę w relacji do krzyża Chrystusa, uświadamia pełnię mysterium iniquitatis, jakie grzech w sobie kryje, by skierować duszę ku nawróceniu, ku otwarciu na mysterium pietatis, które jest tajemnicą samego Chrystusa. Bóg w tajemnicy swego nieskończonego miłosierdzia względem ludzi może sięgnąć ukrytych korzeni ludzkiej nieprawości, by człowieka odkupić i skłonić do pojednania, „bo każdy, kto się narodził z Boga, nie grzeszy, lecz Narodzony z Boga strzeże go, a Zły go nie dotyka" (1 J 5, 18). Owo pojednanie wykazuje poczwórny wymiar, podobnie jak poczwórne były radykalny rozłam i rozdarcie spowodowane przez grzech. Zatem Chrystus Odkupiciel i Sprawca pojednania, który wyzwala człowieka z grzechu w każdej jego postaci, uzyskuje dla niego pojednanie z Bogiem (por. Rz 5, 10-11; 2 Kor 5, 18-20), z braćmi (por. $\mathrm{J}$ 11, 52), z sobą samym (por. Rz 5, 11) i z całym stworzeniem (por. Kol 1, 19-20; Rz 8, 21; 2 P 3, 13; Ap 21, 5). Przywraca jednocześnie, dzięki Mysterium Crucis, przymierze z Bogiem (wymiar wertykalny), by w ten sposób „zniszczyć

${ }^{40}$ Mszał rzymski dla diecezji polskich, Poznań 1986, s. 325*; por. RP 4, 10.

${ }^{41}$ Por. DV 27-28, 37. 
dzielący na mur" (Ef 2, 14) wzniesiony przez grzech (wymiar horyzontalny) ${ }^{42}$. Chrystus połączył więc to, co zostało rozerwane przez grzech, i zniszczył tym samym jego moc oraz potęgę tego, który do niego podżegał. Jednając człowieka ze sobą, uczynił go „nowym stworzeniem” (2 Kor 5, 17-18), obdarzył swą łaską, która przywraca wieź z Bogiem. Można zatem powiedzieć za Alfonsem Skowronkiem, iż Chrystus więcej przyniósł, niż Adam stracił, a człowiek więcej wygrał z Bogiem, niż przegrał z Szatanem. Chrystus bowiem nie tylko leczy rany, lecz także wzmacnia i ubogaca ponad miarę $e^{43}$. Jest On zatem Antytezą wszelkiego zła i jeśli się do Niego należy, to nie można należeć do grzechu i diabła (por. $1 \mathrm{~J} 3,1-24$ ).

\subsection{Sakrament pokuty jako kontynuacja Chrystusowego dzieła pojednania}

Wielki proces pojednania, jakiego dokonał Bóg w Chrystusie mocą Ducha Świętego, wciąż trwa w Kościele w mysterium reconciliationis, znajdując wyraz w chrześcijańskiej pokucie i sakramencie pojednania. Pojednanie z Bogiem i z człowiekiem odbywa się w formie sakramentalnej, bowiem wszystkie akty pojednania między ludźmi i ludzi z Bogiem mają źródło w historiozbawczej działalności Chrystusa. Pojednanie stanowi część historii zbawienia, czyn Pana w Jego Kościele i przez Kościół, który tworzy do tego odpowiednią przestrzeń. Wszystkie sakramenty to narzędzia w rękach Kościoła, prowadzącego do nawrócenia do Boga i pojednania między ludźmi, a szczególnie ów znak, który ukazuje pokutę i pojednanie, a zarazem je urzeczywistnia. Prawdziwe otwarcie się na to jednające działanie następuje tylko wtedy, gdy człowiek oddaje cześć Bogu i pokłada w Nim ufność. Konieczne jest do tego definitywne porzucenie grzechu dzięki interwencji Ducha Świętego, który porusza serca i kieruje je ku Bogu, a potem pozwala wejść w nowe życie z Chrystusem i wytrwać w nim. Główną misją Chrystusa, którą otrzymał od Ojca było „zgładzenie grzechów świata” oraz dar zbawienia (por. J 1, 29; 3, 16; 10, 10; 12, 47) w Duchu Świętym. Odpuszczając grzechy, Pocieszyciel nie czyni jednak człowieka „nowym stworzeniem” automatycznie, ponieważ grzech nie stanowi faktu czysto jurydycznego, ale jest aktem osobowym. Z tego powodu uczestnictwo w sakramencie pokuty wymaga nawrócenia serca. Dzięki darowi Ducha człowiek może rozpocząć nowe życie w Chrystusie, który usuwa grzech jako Najświętszy Baranek napełniony Duchem i dający Ducha, może wejść w tajemnicę śmierci

${ }^{42}$ Por. DV 32; RP 7, 20, 26.

43 Por. A. Skowronek, S. Czerwik, M. Czajkowski, Sakrament pokuty, dz. cyt., s. 231. 
i chwalebnego zmartwychwstania, przez które Chrystus pokonał grzech, moc Szatana i wszelkie rozdarcie ${ }^{44}$. Doskonale ujął to Janusz Królikowski:

jest to sakrament, w którym urzeczywistnia się wzajemna relacja, wcielana po ludzku, Jezusa Chrystusa Odkupiciela i wierzącego-grzesznika, w czym uczestniczy Kościół jako Matka pokutująca i uświęcająca. Dokonuje się to na mocy uczestniczenia w obiektywnej rzeczywistości pojednania dokonanego przez Chrystusa, osądzającego swoją męką i śmiercią ludzki grzech. Spowiedź jawi się więc jako sakrament zstępującej miłości Boga, która w Kościele zniża się do człowieka, aby dać mu się łaskawie do dyspozycji, jeśli chce przekroczyć samego siebie w swojej sytuacji grzechu. W sakramencie pokuty i pojednania ma więc miejsce teofania Boga Odkupiciela i powrót człowieka - w Chrystusie do Ojca mocą Ducha Świętego ${ }^{45}$.

Sakrament pojednania ma zatem charakter wydarzenia uczestniczącego w Tajemnicy Paschalnej Chrystusa i Kościoła, stanowiącej punkt kulminacyjny dzieła odkupienia i urzeczywistnienia się Bożego miłosierdzia. Uczestniczy więc w poczwórnym pojednaniu tego, co rozdzielił grzech, popełniony za podszeptem diabła.

Po pierwsze, najcenniejszym owocem przebaczenia otrzymanego w tym sakramencie jest pojednanie z Bogiem - to Chrystus odpuszcza grzech w mocy Ducha Świętego, jednając grzesznika z Ojcem, a zatem grzesznik, który wchodzi na drogę pokuty, wraca do Ojca, który „pierwszy nas umiłował” (1 J 4, 19), do Chrystusa, który wydał siebie za nas (por. Ga 2, 20; Ef 5, 25) i do Ducha Świętego, który został obficie na nas wylany (por. $\left.\mathrm{Tt}_{3}, 6\right)^{46}$.

Po drugie, zjednoczenie z Trójjedynym Bogiem rodzi dalsze pojednania, naprawiające pozostałe rozdarcia spowodowane przez grzech, a mianowicie, penitent jedna się z sobą w głębi własnego ,ja”, odzyskując wewnętrzną prawdę, rozpoznając w sobie Boży obraz, łaskę, dary Ducha i wyzwalając się od determinizmu własnego egoizmu. Poprzez wejście w krąg oddziaływania

${ }^{44}$ Por. B. Mokrzycki, Kościół w oczyszczeniu, Warszawa 1986, s. 15; A. Skowronek, S. Czerwik, M. Czajkowski, Sakrament pokuty, dz. cyt., s. 100; K. Guzowski, Duch dialogujący, Lublin 2016, s. 249-250; RP 27.

${ }^{45}$ J. Królikowski, Sakrament pokuty i pojednania. Kryzys współczesny i kryzys doktrynalny, „Teologia w Polsce. Nowa seria” 9 (2015) nr 2 (2015), s. 72.

${ }^{46}$ Por. Obrzędy pokuty dostosowane do zwyczajów diecezji polskich, dz. cyt., Wprowadzenie teologiczno-pastoralne 5 . 
miłości, która integruje osobę, jej dążenia, ukierunkowuje na Boga, człowiek może osiągnąć wewnętrzną jedność i nawiązać autentyczne relacje z innymi. Odrzucenie uczynków ciemności i uwolnienie od winy wyzwala z samozamknięcia, samoubóstwienia, destrukcji kontaktów z innymi i samego siebie. To przezwyciężenie grzechu nie jest sprawą prywatną, ale dokonuje się we wspólnocie Kościoła, który kontynuuje dzieło swego Boskiego Założyciela i jako taki odgrywa istotną rolę w doprowadzeniu grzesznika do pojednania z Bogiem i ze wspólnotą. Wzywa do pokuty przez słowo Boże, staje się narzędziem nawrócenia i rozgrzeszenia, dzięki posłudze nakazanej apostołom przez Chrystusa (por. J 20, 22; Mt 18, 18), zaś cała wspólnota na mocy kapłaństwa powszechnego przyczynia się do nawrócenia i pojednania grzesznika z Bogiem i bliźnimi (por. 1 J 5, 14-16; Jk 5, 16. 19; Ga 6, 1; 2 Tm 2, 25; 4, 2). Jeżeli zaś nie posłucha, zostanie „wydany Szatanowi” (1 Kor 5, 5; por. $1 \mathrm{Tm}$ 1, 20; $2 \operatorname{Tm} 2,26)^{47}$.

Poza tym penitent jedna się z braćmi i z Kościołem, któremu wyrządził krzywdę swą nieprawością i złamał jedność eucharystycznego stołu (por. 1 Kor 5, 6; 12, 26), oraz zyskuje równowagę w swej relacji do świata stworzonego.

Wyznanie grzechu podczas spowiedzi odziera go niejako z jego mocy, wydobywa z ciemności na światło Chrystusa, który ogarnia grzesznika swą łaską i miłosierdziem (por. Ps 32; 130; Prz 28, 13; 1 J 1, 8-9). Rozpada się zatem mur, jakim grzech odgradzał człowieka od Boga, drugiego człowieka i Kościoła oraz od siebie samego i całego stworzenia. Tym samym zniszczone zostają zamysły złego ducha, by upodlić istotę najbardziej ukochaną przez Stwórcę.

47 Zob. RP 31; por. J. Orzeszyna, Społeczno-eklezjalny wymiar sakramentu pokuty, dz. cyt., s. 137, 285. Podatność na szatańskie wpływy poza dobroczynną przestrzenią pokuty zauważają już autorzy wczesnochrześcijańscy. Hermas w Pasterzu pisał: „Zna On bowiem tajniki serc ludzkich i jako wszystkowiedzący przewidział już z góry, że człowiek będzie słaby, a chytry diabeł będzie usiłował szkodzić sługom Bożym; ponieważ zaś Pan jest zarazem miłosierny, ulitował się nad swymi stworzeniami i ustanowił tę pokutę, mnie zaś zlecił nad nią władzę" (Przykazanie 4, 3, cyt. za: A. Skowronek, S. Czerwik, M. Czajkowski, Sakrament pokuty, dz. cyt., s. 143). Z kolei Tertulian przestrzegał przed „diabelską trucizną”, która sączy się w serca wierzących po chrzcie, dlatego potrzeba „drugiej pokuty” (Tertullianus, De poenitentia, in: Quinti Septimii Florentis Tertulliani opera omnia, accurante J.-.P. Migne, Parisiis 1844, c. 7, col. 1241 (Patrologiae Cursus Completus. Series Latina [dalej: PL], 1). Natomiast papież Leon Wielki uwidacznia, że w Wielkim Poście Szatan „spostrzega, jak ludzie upadli i uwikłani w sidła jego podstępu, obmywają się łzami pokuty, jak apostolski klucz otwiera im podwoje miłosierdzia i daje dostęp do lekarstwa pojednania" (Leo Magnus, Sermo XLIX, in: Leonis Magni opera omnia, accurante J.-.P. Migne, Parisiis 1846, c. 3, col. 303 (PL 54)). 


\section{Sakrament pokuty jako skuteczna broń przeciw duchowi ciemności}

Aspekt wyzwalający sakramentu pojednania nie ogranicza się do duchowego uzdrowienia, ale ma też charakter antydemoniczny. Jednym z aspektów władzy odpuszczania grzechów, którą Chrystus przekazał apostołom (por. Mt 16, 17-19; 18,$18 ;$ J 20, 23), jest bowiem władza uwalniania człowieka spod wpływu złych duchów. Dlatego Tertulian nazywał spowiedź „ratunkiem przeciw piekłu”48, a Marcin Luter stwierdził:

Spowiedzi nie pozwolę sobie przez nikogo odebrać i nie oddałbym jej za wszystkie skarby świata. Wiem bowiem, ile dała mi pociechy i siły. Nikt nie wie, czym ona jest dla tego, kto często i wiele zmagał się z diabłem. Tak, dawno byłbym zdławiony przez diabła, gdyby nie ocaliła mnie spowiedź ${ }^{49}$.

Z tego powodu Chrystus, a potem Jego Kościół, głosił potrzebę skruchy serca i wzywał do duchowej trzeźwości, bo „przeciwnik wasz, diabeł, jak lew ryczący krąży, szukając, kogo pożreć” (1 P 5, 8). Skrucha serca to pierwsze pęknięcie w barierze, jaką pragnie wznieść duch ciemności, odgradzając człowieka do Boga i bliźnich. Żeby to osiągnąć i wyrzec się Szatana oraz „wszelkich spraw jego", należy najpierw uświadomić sobie zło własnego grzechu i jego wielowymiarowe skutki (por. Ps $51,5-6)^{50}$. Konieczna jest do tego wiara w Boga osobowego, wobec którego człowiek czuje się odpowiedzialny, oraz poznanie i uznanie, że każda wina wobec człowieka jest jednocześnie winą przed Bogiem. Mimo że jest to czyn człowieka, to u jego korzeni leży łaska Boga miłosiernego, która przesądza o skuteczności pokuty. Grzesznik musi ze swej strony wyznać swoją winę (por. Ps 32, 3-5; $1 \mathrm{~J} 1,9$ ) , $^{51}$ zerwać z grzechem stanowiącym demoniczną barierę oddzielającą go od Stwórcy i bliźniego oraz

${ }^{48}$ Cyt. za: Chrzest i pokuta w Kościele starożytnym, dz. cyt., s. 181.

49 Cyt. za: A. Skowronek, S. Czerwik, M. Czajkowski, Sakrament pokuty, dz. cyt., s. 93.

${ }^{50}$ Cezary z Arles zaleca, by na początku procesu pojednania z Bogiem wzbudzić w sobie zbawienną bojaźń Bożą, przestać być obrońcą swych grzechów i stać się ich oskarżycielem. Trzeba też zdystansować się od grzechu, znienawidzić go, by zbliżyć się do Boga, który nienawidzi grzechu. Zob. Kazanie 67, 1, w: Cezary z Arles, dz. cyt., s. 170.

${ }^{51}$ Andrzej z Krety opisuje ten akt w ten sposób: „Przebudź się, duszo moja, rozmyślaj o swoich czynach, które uczyniłaś, weź je przed swoje oczy i wylej krople twoich łez, mów odważnie Chrystusowi czyny swoje i usprawiedliw się" (Wielki Kanon Pokutny, dz. cyt., s. 15). Z kolei Tomasz z Akwinu przypominał, że każdy grzech może być zmazany przez pokutę, zaś jedynymi, którzy nie mogą 
zadośćuczynić za niego poprzez zewnętrzne akty, świadczące o radykalnej i autentycznej wewnętrznej przemianie (por. Mt 3, 8; Łk 9, 62; 13, 5). Tomasz z Akwinu pisał, że spowiedź jest dla człowieka, a skruchę i zadośćuczynienie czyni się dla Boga, przy czym te dwa ostatnie wymagają, by pokutujący człowiek był zjednoczony z Bogiem przez miłośćs ${ }^{2}$. Ona bowiem „zakrywa wiele grzechów” (1 $\mathrm{P} 4$, 8; por. Łk 7, 47), wyzwala z więzów grzechu i odstrasza złego ducha (por. Jk 4, 7).

Ciągle trzeba jednak czuwać, żeby nie dać się wciągnąć kusicielowi w kolejną niewinnie wyglądającą pułapkę i nie wybrać zła, nawet w sprawach małej wagi. Dlatego Cezary z Arles zachęcał do codziennej pokuty przez całe życie ${ }^{53}$, a Jan Paweł I do stałego odkrywania i wytrwałego urzeczywistniania w sobie miłości miłosiernej Boga ${ }^{54}$.

Całkowita wewnętrzna zmiana, dzięki której człowiek zaczyna właściwie układać swoje życie (metanoia), winna łączyć się z zewnętrznymi aktami pokuty, takimi jak modlitwa, post, akty czci i dzieła miłosierdzia, które weryfikują tę przemianę. Te dzieła odwracają bowiem od ciemności grzechu, a ukierunkowują ku światłu Chrystusa, które rozświetla i ujawnia zło, jakie się w grzechu kryje ${ }^{55}$. Dzięki praktykowaniu miłości Boga i bliźniego przez człowieka diabeł nie ma punktu zaczepienia, dzięki któremu mógłby bez przeszkód sączyć w ludzką duszę truciznę kłamstwa, należącego do jego istoty (por. J 8, 44), a poprzez modlitwę i post człowiek jest w stanie przeciwstawić się nawet najbardziej zaciekłym i uporczywym atakom ducha ciemności (por. Mt 17, 21; Mk 9, 29) ${ }^{56}$.

mieć odpuszczonego grzechu są ci, którzy tego nie chcą, a mianowicie demony i potępieni (Tomasz z Akwinu, Suma teologiczna, t. 29: Sakrament pokuty (3, q. 84-9o), dz. cyt., zag. 86, art. 1, wykład).

${ }^{52}$ Por. Tomasz z Akwinu, Suma teologiczna, t. 30, dz. cyt., zag. 9, art. 1, rozwiąz. 2.

53 Zob. Cezary z Arles, Kazanie 61, 1-3; w: Cezary z Arles, dz. cyt., s. 175.

54 Zob. Jan Paweł II, Encyklika Dives in misericordia, nr 14, w: Encykliki Ojca Świętego Jana Pawła II, Kraków 2005.

55 Por. Paulus PP. vi, Constitutio apostolica Paenitemini, nr 1, „Acta Apostolicae Sedis” 58 (1966), s. 178 .

${ }^{56}$ „Nie leń się, duszo, gdy wróg ciebie atakuje, ale przez modlitwy i post niech będzie on odpędzony od nóg twoich” (Andrzej z Krety, Wielki Kanon Pokutny, dz. cyt., s. 33); „Chrystus był kuszony, diabeł kusił, pokazując kamienie, aby zostały przemieniony w chleb, wywiódł Go też na górę, aby zobaczył w jednej chwili wszystkie królestwa świata. Ulęknij się duszo, tego oszustwa, czuwaj i nieustannie módl się do Boga" (Andrzej z Krety, Wielki Kanon Pokutny, dz. cyt., s. 63, 65); „Wiem, Miłosierny, że zgrzeszyłem, skalałem naczynie mego ciała, lecz przyjmij mnie w pokucie i wezwij do poznania prawdy, abym nie stał się zdobyczą i pokarmem wroga, sam, Zbawco, ulituj się nade mną" (Andrzej z Krety, Wielki Kanon Pokutny, dz. cyt., s. 111). 
Jezus i apostołowie często przestrzegali przed Złym i jego aniołami, które próbują nieustannie nakłaniać człowieka do grzechu, by stał się „dzieckiem diabła” (1 J 3, 8). Jednak Bóg, „litościwy, miłosierny, nieskory do gniewu i bogaty w łaskę" (Jl 2, 13), który daje nowe serce i nowego ducha prawdziwie pokutujące$\mathrm{mu}$ (por. Ps 51, 12; Ez 11, 19; 18, 31; 36, 26), nie pozwoli kusić człowieka ponad to, co może on znieść, i wskazuje sposób pokonania pokusy (por. 1 Kor 10, 13). Szatan bowiem próbuje wiarę człowieka, a Chrystus ją wspiera (por. Łk 22, 31-32).

Apostoł Paweł wzywa z kolei do odrzucenia „uczynków ciemności” i przyobleczenia się w „zbroję światła” (Rz 13, 12), by móc się „ostać wobec podstępnych zakusów diabła”, ponieważ „nie toczymy walki przeciw krwi i ciału, lecz przeciw Zwierzchnościom, przeciw Władzom, przeciw rządcom świata tych ciemności, przeciw duchowym pierwiastkom zła na wyżynach niebieskich” (Ef 6, 11-12). Dlatego poleca ubrać się w „pełną zbroję Bożą” (Ef 6, 13), by przeciwstawić się ich atakom, dzięki prawdzie, sprawiedliwości, gotowości głoszenia Ewangelii o pokoju, modlitwie w Duchu oraz wierze zdolnej „zgasić wszystkie rozżarzone pociski Złego" (Ef 6, 16). W tym świetle należy też widzieć cel i owoce istnienia sakramentu pokuty i pojednania. Ten znak pojednania z Bogiem i z bliźnimi zbawczą mocą Tajemnicy Paschalnej Chrystusa stanowi kontynuację misji Syna Bożego, który „objawił się po to, by zniszczyć dzieła diabła" (1 J 3, 8). Widać to nie tylko w teologii tego sakramentu, lecz także $\mathrm{w}$ jego aspekcie liturgicznym.

\subsection{Antydemoniczny charakter elementów sakramentu pokuty i pojednania}

Obrzędy liturgiczne sakramentu pokuty rzadko wspominają o działaniu Szatana wprost. Często jednak jest w nich mowa o grzeszności człowieka i wyzwoleniu przez miłosiernego Boga od mocy zła, ciemności i więzów grzechu, czyli o pojednaniu, zbawieniu i nowym życiu dzięki mocy Ducha, które same w sobie mają wymiar antydemoniczny. W Rytuale rzymskim aspekt ten jest najbardziej widoczny w modlitwie kapłana podczas nabożeństwa pokutnego: „Boże, Stwórco i Odkupicielu rodzaju ludzkiego, Ty przez Krew swojego jedynego Syna odkupiłeś człowieka, którego zazdrość szatana pozbawiła szczęścia wiecznego. Przez Ducha Świętego daj nowe życie swoim wiernym, których nie chcesz zostawić pod władzą śmierci. [...] Ulecz ich rany, podaj zbawczą dłoń upadłym, [...] aby się nie cieszył nieprzyjaciel zbawienia, aby wieczna śmierć nie ogarnęła odrodzonych w sakramencie chrztu świętego" 57.

Wprowadzenie teologiczno-pastoralne do Rytuału powtarza, że podczas obrzędu pojednania nigdy nie należy opuszczać modlitwy Ojcze nasz, która

\footnotetext{
${ }^{57}$ Obrzędy pokuty dostosowane do zwyczajów diecezji polskich, dz. cyt., s. 201.
} 
kończy się błaganiem o uwolnienie od Złego ${ }^{58}$. Papież Franciszek podkreślił, iż to wyrażenie wskazuje na istotę osobową, która dręczy ludzi, a „Jezus nauczył nas, abyśmy codziennie prosili o to wyzwolenie, aby jego moc nie panowała nad nami"59. Sama jednak struktura obrzędu tego sakramentu zbudowana jest w ten sposób, aby jak najlepiej przygotować się na spotkanie z przebaczającym Chrystusem i uzyskać z Nim jedność, pozbywając się jednocześnie balastu i więzów, jakie nakładał na człowieka grzech, łącząc go ze światem ciemności.

Pierwszym krokiem ku pojednaniu jest rachunek sumienia, który polega przede wszystkim na zrozumieniu swej grzeszności wobec świętego i kochającego bezwarunkowo Boga, „zastanowieniu się” (Łk 15, 17) nad sobą, swoimi czynami bądź zaniedbaniami wobec Niego, bliźnich i siebie samego. Bez poczucia grzechu człowiek nie zwraca się ku Bogu, nie pokutuje. Zaczyna myśleć, że jest bezgrzeszny i samowystarczalny, a w końcu stwierdza, że nie potrzebuje Boga i Jego zbawienia, ponieważ jest w stanie zapewnić je sobie sam, co stanowi echo ulegnięcia pokusie „starożytnego węża” (Ap 12, 9) z Księgi Rodzaju (3, 5-7).

Żal za grzechy to uświadomienie sobie odpowiedzialności przed osobowym Bogiem za to, że zepsuło się relację miłości, którą Stwórca sam zawiązał. Konieczny jest w tym akt woli odwracającej się od zła, potępiającej swój grzech i zwracającej się ku dobru, dzięki oświeceniu łaską Bożą. Wacław Świerzawski porównał żal za grzechy do decyzji podobnej do zwycięstwa nad śmiercią jest bowiem przez uczestnictwo w śmierci Chrystusa na krzyżu równocześnie zmartwychwstaniem. Człowiek z niewolnika staje się istotą wolną ${ }^{60}$. Brak żalu jest cechą szatańską - zły duch czyni zło dla samego zła, nigdy nie żałuje raz powziętej decyzji, gotów szkodzić człowiekowi, aż nadejdzie koniec czasów (por. Ap 20, 7-10).

Z kolei poprzez mocne postanowienie poprawy penitent obiecuje uwolnić się od przywiązania do przynajmniej jednej najważniejszej złej postawy wobec Boga, innych ludzi i siebie samego, w odpowiedzi na wezwanie Jezusa do metanoi, do praktycznego przejawu bycia „nowym stworzeniem” (2 Kor 5, 17), by stawić czoła Złemu (por. Ef 6, 11; Jk 4, 7). W tym celu musi wypełnić swe życie uczynkami miłości, by w ten sposób konkretnie zamanifestować pragnienie pozostania jedności z Bogiem. Tam, gdzie w ludzkiej rzeczywistości nie ma Boga, nigdy nie ma próżni, zawsze wypełnia ją Szatan (por. Mt 12, 43-45).

${ }^{8}$ Zob. Obrzędy pokuty dostosowane do zwyczajów diecezji polskich, dz. cyt., Wprowadzenie teologiczno-pastoralne 27, 36 .

59 GE 160.

${ }^{60}$ Por. W. Świerzawski, Sakramenty święte. Sakrament pokuty i pojednania, dz. cyt., s. 173-174. 
Otwarcie serca i wyznanie grzechów przed Bogiem z bojaźnią i pokorą wypływa z prawdziwego poznania siebie przed Jego obliczem i z żalu za grzechy. Przez wypowiedzenie swej winy człowiek otwiera się na Boże miłosierdzie i wierzy, że Chrystus zgładzi jego grzechy mocą swej miłości, dzięki której na krzyżu pojednał świat z Ojcem w Duchu Świętym. W absolucji zbawcza moc Tajemnicy Paschalnej Chrystusa zostaje ogłoszona penitentowi jako "miłosierdzie mocniejsze od winy i zniewagi”, jest to znak „zmartwychwstania” ze „śmierci duchowej”' ${ }^{\prime \prime}$. W konsekwencji znika mur oddzielający penitenta od Stwórcy, od Kościoła, od bliźnich i całego stworzenia. Zostaje unicestwiony również balast, który niósł w sobie grzesznik, a powstały wskutek jego nieprawości. W konsekwencji przerwane zostają więzy, jakie łączyły go ze światem ciemności. Miłosierne wybaczenie ze strony Trójjedynego nie zwalnia jednak człowieka z zachowania czujności i trzeźwości ducha, by nie ulec kolejnym atakom Złego, bardziej wysublimowanym i dostosowanym do sytuacji.

Zadośćuczynienie za krzywdy to świadczenie o nawróceniu i odwrocie od niewoli grzechu i Szatana. Taka poprawa życia wymaga praktykowania prawdziwej miłości Boga i bliźniego. Ponadto, wyrównanie szkody stanowi uczestnictwo w tajemnicy i kenozie Chrystusa, który zadośćuczynił wobec Bożej sprawiedliwości. Zadośćuczynienie sakramentalne ułatwia odpokutowanie kary doczesnej, zaś każdy czyn pokutny, taki jak modlitwa, post czy też czyny miłości, posiada cechy lecznicze i zadośćczyniące ${ }^{62}$. Dzięki niemu penitent „na nowo włącza się w misterium zbawienia i wytęża siły ku temu, co jest przed nim" ${ }^{63}$. Sensem zadośćuczynienia jest więc dziękczynienie Bogu za dary doczesne i duchowe oraz wyrównanie spraw z ludźmi, by nie pojawił się podział i rozłam - domena i znak rozpoznawczy Szatana. Sakrament pokuty i pojednania niesie ze sobą jeszcze inne konsekwencje, chroniące przed jego wpływem.

\subsection{Owoce sakramentu pokuty i pojednania}

Pojednanie z Bogiem, które polega na otrzymaniu Jego przebaczenia, łaski Ducha Świętego, osiągnięciu głębszej komunii z Chrystusem, aż do utożsamienia się z Nim, to główny owoc sakramentu pokuty, natomiast pojednanie z samym sobą, z Kościołem i bliźnimi oraz całym światem stworzonym to wypływające z niego konsekwencje. Dzięki ponownemu zawiązaniu węzła przyjaźni i miłości z Bogiem człowiek otrzymuje bowiem nową jakość bytu

61 RP 31.

${ }^{62}$ Por. A. Drożdż, Sakrament pojednania z Bogiem i z Kościołem, cz. 4, Tarnów 2002, s. 93-94.

${ }^{63}$ Obrzędy pokuty dostosowane do zwyczajów diecezji polskich, dz. cyt., Wprowadzenie teologiczno-pastoralne $6 \mathrm{c}$. 
i działania, rodzi się na nowo (por. 1 J 2, 29; 3, 9; 4, 7; 5, 11), zyskuje wolność dziecka Bożego (por. Rz 8, 16; 2 Kor 3, 17), oczyszczenie i odnowienie oraz pokój i światłość sumienia, by uświadomić sobie to, co jest dobre, a co złe, i postępować na drodze do doskonałości. Wzrasta również poznanie siebie, pokora, miłość, wzmocniona zostaje wola, by naśladować Chrystusa, żyć życiem Trójcy Świętej i poddać się kierownictwu Ducha Prawdy (por. Ga 5, 18), a zatem doznać „przebóstwiającej przemiany” ${ }^{64}$.

Ta przemiana powoduje również otwarcie się na innych. Łaska Boża otrzymana w spowiedzi świętej przywraca bowiem lub pomnaża łaskę uświęcającą oraz łaskę uczynkową, by można było dążyć do poprawy nie tylko własnego życia, lecz także relacji z bliźnimi. Dzięki temu wzmacnia się także Kościół, ponieważ zarówno grzech, jak i wyzwolenie z niego ma wymiar społeczny. Człowiek może w lepszy sposób spełniać swe powołanie w Kościele i w świecie.

Dzięki temu impulsowi ku dobremu życiu człowiek zdaje sobie sprawę, że dotąd tkwił w duchowej inercji i zawieszeniu, niczym niewolnik poddany dyktatowi swych żądz i determinizmowi zła. W przestrzeni grzechu był podatny na wszelkie zabiegi „ojca kłamstwa”. Powrót z tej ciemności do światłości Chrystusa poprzez sakrament pokuty jest prawdziwym wyzwoleniem, oswobodzeniem od groźby kary wiecznej, w którą człowiek sam się wpędził z pomocą Złego, oraz zapewnia moc do walki duchowej z mocami ciemności, pociechę duchową wobec trudności związanych z atakami Szatana.

Ponadto sakrament pokuty i pojednania jest niezwykle ważnym elementem na drodze wyzwolenia człowieka $z$ więzów diabła poprzez egzorcyzmy. Sytuacje omówione powyżej dotyczą przede wszystkim codziennej, zwykłej walki duchowej, w której szczera skrucha i spowiedź pomagają kształtować sumienie, walczyć ze złymi skłonnościami, wzmacniają wiarę, nadzieję i miłość oraz pozwalają człowiekowi poddać się ożywiającemu prowadzeniu Ducha Świętego i jako takie są „potężną bronią, jaką daje nam Pan” przeciw „podstępnym atakom diabła” (Ef 6, 16) ${ }^{65}$. Są jednak sytuacje, w których człowiek doprowadza do całkowitego przejęcia kontroli nad swoim życiem przez złego ducha. Egzorcyści wskazują na zaniedbywanie sakramentów, zwłaszcza pokuty, jako główną przyczynę braku łaski w walce z Szatanem i poddania się jego

${ }^{64}$ W. Świerzawski, Sakramenty święte. Sakrament pokuty i pojednania, dz. cyt., s. 109; por. J. Orzeszyna, Społeczno-eklezjalny wymiar sakramentu pokuty, dz. cyt., s. 132.

${ }^{65}$ Por. GE 162. 
niszczącej mocy oraz przypominają o uzdrawiającej funkcji tego sakramentu ${ }^{66}$. Jest on bowiem nazywany „najlepszym egzorcyzmem” i „środkiem najbardziej bezpośrednim, który zwalcza szatana”, ponieważ „jest sakramentem, który wyrywa dusze złemu duchowi, daje siłę przeciwko grzechowi, jednoczy coraz bardziej z Bogiem, skłaniając dusze do większego dostosowania ich życia do woli Bożej” ${ }^{67}$. Także rytuał egzorcyzmów podkreśla „fundamentalną rolę łaski płynącej z sakramentów, a zwłaszcza z częstego udziału w celebracji pokuty”, by otrzymać „moc do osiągnięcia pełnej wolności dzieci Bożych" ${ }^{\text {" }}$. Następnie zaleca, by wierny dręczony przez złego ducha, jeśli tylko potrafi, przystępował częściej do sakramentu pojednania, zaś po uwolnieniu dzięki egzorcyzmom, nie porzucał tej praktyki i stosował ją ustawicznie wraz z wdzięczną modlitwą, udziałem w Eucharystii i życiem wypełnionym uczynkami miłości ${ }^{69}$.

Sakrament pokuty i pojednania jako kontynuacja odkupieńczej mocy Tajemnicy Paschalnej Chrystusa - Jego wielkiego dzieła pojednania - stanowi zatem potężną barierę i broń wymierzoną w największego nieprzyjaciela człowieka, „zabójcy od początku” (J 8, 44), który pragnie unicestwić życie Boga w Jego ukochanym stworzeniu. Dlatego, z jednej strony, nie należy lekceważyć antydemonicznego wymiaru sakramentu pokuty i pojednania, redukując go do wydarzenia psychologicznego czy leczniczego, a z drugiej strony nie można demonizować rzeczywistości, widząc diabła jako bezpośredniego sprawcę wszelkiego zła.

Jedną z takich skrajności, która pojawiła się w ostatnim czasie, jest zjawisko tzw. spowiedzi furtkowej, w sposób nieuprawniony łączącej elementy sakramentu pokuty z elementami psychoterapii i egzorcyzmu, szukającej w ten sposób „furtek”, które grzech osobisty bądź „pokoleniowy” otwarł przed Szatanem, dając mu władzę nad człowiekiem. Komisja Nauki Wiary Konferencji Episkopatu Polski wydała opinię teologiczną w tej sprawie, stwierdzając między innymi, że wprowadzenie w obrzęd sakramentu pokuty modlitwy o uwolnienie, czasami nawet pod postacią egzorcyzmu uroczystego, stanowi poważne nadużycie. Jest to niedopuszczalne, ponieważ rozmywa skuteczność udzielonego

${ }^{66}$ Por. G. Amorth, Nowe wyznania egzorcysty, Częstochowa 1998, s. 75; J. Szymborski, „Cały świat leży w mocy Złego" (1 J 5, 19), w: B. Barkowski, A. Posacki, W blasku Chrystusa i cieniu szatana, Warszawa 2004, s. 178.

${ }^{67}$ G. Amorth, Nowe wyznania egzorcysty, dz. cyt., s. 212-213.

${ }^{68}$ Egzorcyzmy i inne modlitwy błagalne: rytuał rzymski odnowiony zgodnie z postanowieniem świętego Soboru Watykańskiego II, wydany z upoważnienia papieża Jana Pawła II, Katowice 2002, Wprowadzenie teologiczne i pastoralne, 9.

${ }_{69}$ Zob. Egzorcyzmy i inne modlitwy błagalne..., dz. cyt., 32, 36. 
rozgrzeszenia i nie uwzględnia prawdy o tym, że już sama spowiedź jest egzorcyzmem, a absolucja sprawia całkowite usprawiedliwienie i uwolnienie od winy. Nie należy zatem szukać w przeszłości swojej lub rodziny „furtek”, które grzech otworzył dla złego ducha, ponieważ podważałoby to ważność dotychczasowych spowiedzi, niezmierzoną moc miłosierdzia Bożego oraz sugerowałoby istnienie tak zwanego "grzechu pokoleniowego". Ponadto bardzo rozbudowany rachunek sumienia, koncentrujący się na szukaniu „furtek” dla diabła stanowi skupianie na nim uwagi jako głównym sprawcy zła, nie uwzględniając prawdy o człowieku ${ }^{70}$. Komisja podkreśliła też fakt, że Szatan i jego działanie stanowi jedno ze źródeł grzechu, lecz nie należy ich przesadnie podkreślać, bo zły duch nie jest ani równym przeciwnikiem Boga, ani nie przysługuje mu żadna władza nad człowiekiem. Został on pokonany przez Chrystusa na krzyżu w sposób nieodwołalny i ostateczny ${ }^{71}$. Zdaniem komisji „W takiej perspektywie «spowiedź furtkowa» jawi się nawet jako szatańska prowokacja. Sakrament pokuty zamiast stać się miejscem spotkania człowieka z miłosierną miłością Boga, która uzdrawia i leczy, staje się napawającą lękiem konfrontacją z siłami zła. Dlatego zamiast zamykać «furtki» przed szatanem, należy jeszcze bardziej otwierać penitenta na Chrystusa"72.

Wobec tego niezwykle ważne jest przypomnienie i wdrożenie w życie słów Chrystusa: „czuwajcie i módlcie się, abyście nie ulegli pokusie” (Mt 26, 41; Mk 14, 38). Zły nieustannie będzie szukał słabego punktu w „zbroi światła” $(\mathrm{Rz} 13,12)$, by zniszczyć człowieka. Atak na sakrament pokuty, czy to przez odwodzenie od niego ludzi, czy też przez rozmywanie jego sensu i koncentrację uwagi na sobie jako kimś ważniejszym niż jest w rzeczywistości, to kolejny przejaw mysterium iniquitatis w świecie i dowód na to, że sakrament pojednania czyni siłom zła olbrzymie szkody, kiedy jest przyjmowany z wiarą i skruchą serca.

\section{Abstrakt}

Sakrament pokuty i pojednania to kontynuacja zbawczej mocy Tajemnicy Paschalnej Chrystusa jako wielkiego dzieła pojednania człowieka z Bogiem, z bliźnimi, z samym sobą i z całym światem stworzonym. Jednoczy w ten sposób to, co zostało rozdzielone

${ }^{70}$ Por. M. Jagodziński, „Zwyczajne” działanie Boga..., dz. cyt., s. 57-58.

${ }^{71}$ Por. Opinia teologiczna Komisji Nauki Wiary KEP w sprawie tzw. spowiedzi furtkowej, dz. cyt., nr 11.

${ }^{72}$ Opinia teologiczna Komisji Nauki Wiary KEP w sprawie tzw. spowiedzi furtkowej, dz. cyt., nr 9. 
przezludzki grzech, popełniony za podszeptem diabła. Przebaczenie i łaska otrzymane od Boga w tym sakramencie pozwala pokonać rozłam i podziały, które są znakiem rozpoznawczym działania złego ducha oraz wziąć udział w zwycięstwie Chrystusa nad grzechem, śmiercią i Szatanem. Sama struktura spowiedzi pozwala odkryć antydemoniczny charakter tego sakramentu oraz prawdziwą wolność dzieci Bożych w Chrystusie.

\section{SŁoWA KLUCzowe}

sakrament pokuty i pojednania, Tajemnica Paschalna, grzech, pokusa, Szatan

\section{Abstract \\ Antidemonic Feature of Sacraments: the Sacrament of Penance and Reconciliation}

The Sacrament of Penance and Reconciliation is the continuation of the saving power of the Paschal Mystery of Christ as a great work of reconciliation of man with God, with other people, with himself and with the whole created world. It unites in this way what has been separated by human sin, committed at the instigation of the devil. The forgiveness and grace received from God in this sacrament allows to overcome the disruption and divisions that are the hallmark of the evil spirit and to participate in the victory of Christ over sin, death and Satan. The very structure of confession allows to discover the antidemonic dimension of this sacrament and the true freedom of God's children in Christ.

\section{KEYWORDS}

The Sacrament of Penance and Reconciliation, the Paschal Mystery, sin, temptation, Satan

\section{BiBLIOGRAFIA}

Amorth G., Nowe wyznania egzorcysty, Częstochowa 1998.

Andrzej z Krety, Wielki Kanon Pokutny, tłum. H. Paprocki, Hajnówka 2004.

Benedykt XVI, Adhortacja apostolska Sacramentum Caritatis, Kraków 2007.

Cezary $z$ Arles, oprac. A. Żurek, Kraków 2003.

Chrzest i pokuta w Kościele starożytnym, oprac. J. Słomka, Kraków 2004.

Drożdż A., Sakrament pojednania z Bogiem i z Kościołem, cz. 4, Tarnów 2002.

Ficoń M., Antydemoniczny charakter sakramentu chrztu świętego i sakramentu bierzmowania, „Analecta Cracoviensia” 48 (2016), s. 25-40. 
Ficoń M., Antydemoniczny charakter sakramentu Eucharystii, „Analecta Cracoviensia” 49 (2017), s. 7-28.

Franciszek, Adhortacja apostolska Gaudete et exsultate, http://w2.vatican.va/content/francesco/pl/apost_exhortations/documents/papa-francesco_esortazione-ap_20180319_gaudete-et-exsultate.html (13.06.2018).

Guzowski K., Duch dialogujacy, Lublin 2016.

Jagodziński M., „Zwyczajne” działanie Boga w sakramentach w kontekście kontrowersyjnych koncepcji teologiczno-pastoralnych, „Studia Teologii Dogmatycznej” 3 (2017), s. 49-64.

Jan Paweł II, Adhortacja apostolska Reconciliatio et poenitentia, Libreria Editrice Vaticana 1984.

Jan Paweł II, Encyklika Dives in misericordia, w: Encykliki Ojca Świętego Jana Pawła II, Kraków 2005, s. 77-139.

Jan Paweł II, Encyklika Dominum et Vivificantem, Warszawa 2007.

Jan Paweł II, Encyklika Ecclesia de Eucharistia, Warszawa 2007.

Jan Paweł II, Encyklika Veritatis splendor, Warszawa 2007.

Jan Paweł II, List apostolski Mulieris dignitatem, w: Jan Paweł II, Dzieła zebrane, t. 3, Kraków 2007, s. 290-330.

Jan Paweł II, List apostolski Parati semper do młodych całego świata z okazji Międzynarodowego Roku Młodzieży, w: Jan Paweł iI, Dzieła zebrane, t. 3, Kraków 2007, s. 251-275.

Katechizm Kościoła Katolickiego, Poznań 1994.

Królikowski J., Sakrament pokuty i pojednania. Kryzys współczesny i kryzys doktrynalny, „Teologia w Polsce. Nowa Seria” 9 (2015) nr 2, s. 53-74.

Leo Magnus, Sermo XLIX, in: Leonis Magni opera omnia, accurante J.-.P. Migne, Parisiis 1846, col. 301-305 (Patrologiae Cursus Completus. Series Latina, 54).

Mokrzycki B., Kościół w oczyszczeniu, Warszawa 1986.

Mszał rzymski dla diecezji polskich, Poznań 1986.

Obrzędy pokuty dostosowane do zwyczajów diecezji polskich, red. Komisja ds. Kultu Bożego, Katowice 1981.

Opinia teologiczna Komisji Nauki Wiary KEP w sprawie tzw. spowiedzi furtkowej, http://episkopat.pl/decyzja-kep-w-sprawie-tzw-spowiedzi-furtkowej (6.06.2018).

Orzeszyna J., Społeczno-eklezjalny wymiar sakramentu pokuty, Kraków 1996.

Paulus P P. vi, Constitutio apostolica Paenitemini, „Acta Apostolicae Sedis” 58 (1966), s. $177-198$.

Egzorcyzmy i inne modlitwy blagalne: rytuał rzymski odnowiony zgodnie z postanowieniem świętego Soboru Watykańskiego II, wydany z upoważnienia papieża Jana Pawła II, Katowice 2002. 
Skowronek A., Czerwik S., Czajkowski M., Sakrament pokuty, Katowice 1980.

Sobór Watykański II, Konstytucja duszpasterska o Kościele w świecie współczesnym

Gaudium et spes, w: Sobór Watykański II, Konstytucje, dekrety, deklaracje, red. M. Przybył, Poznań 2002, s. 526-606.

Sobór Watykański II, Konstytucja Lumen gentium, w: Sobór Watykański II, Konstytucje, dekrety, deklaracje, red. M. Przybył, Poznań 2002, s. 105-170.

Szymborski J., „Cały świat leży w mocy Złego” (1 J 5, 19), w: B. Barkowski, A. Posacki, W blasku Chrystusa i cieniu szatana, Warszawa 2004, s. 169-179.

Świerzawski W., Sakramenty święte. Sakrament pokuty i pojednania, Wrocław 1984.

Tertullianus, De poenitentia, in: Quinti Septimii Florentis Tertulliani opera omnia, accurante J.-.P. Migne, Parisiis 1844, col. 1223-1248 (Patrologiae Cursus Completus. Series Latina, 1).

Tomasz Akwinu, Suma teologiczna, t. 12: O wadach i grzechach (1-2, q. 71-89), przetłumaczył i objaśnieniami zaopatrzył o. F. W. Bednarski op, London 1965.

Tomasz z Akwinu, Suma teologiczna, t. 29: Sakrament pokuty (3, q. 84-9o), przełożył i w objaśniania zaopatrzył o. R. Kostecki op, London 1969.

Tomasz z Akwinu, Suma teologiczna t. 30: Sakrament pokuty II (Suppl. 1-28), przełożył i w objaśniania zaopatrzył o. F. W. Bednarski op, London 1985. 